J. Perinat. Med.

10 (1982) 167

\section{Fetal anemia and heart rate patterns}

\author{
Veikko Kariniemi \\ 1st Department of Obstetrics and Gynecology, \\ Helsinki University Central Hospital, Helsinki, Finland
}

\section{Introduction}

Fetal heart rate (FHR) changes related to fetal anemia have not been investigated comprehensively. MoDANLOU et al. [16] reported a case of severe fetal anemia due to a massive fetomaternal transfusion of a fetus at 34 weeks of gestation. The newborn did well after cesarean section and neonatal intensive care. More recently, four other case reports on severe fetal anemia have been published [21, 8, 17, 20]. A special morphological FHR pattern, the sinusoidal FHR curve, was observed in all five cases, although it was not recognised in one [21]. MANSEAU et al. [14] were the first to describe the sinusoidal FHR pattern, which they observed in nine $\mathrm{Rh}$-immunized fetuses with poor outcome. Later on, the association between the sinusoidal heart rate pattern and $\mathrm{Rh}$-immunization has been confirmed $[18,7,22]$. The sinusoidal FHR pattern has also been attributed to a more diverse group of fetal distress $[13,1,3,4,5$, $15,12,23]$ and impending fetal death. These reports have in common that fetal hemoglobin $\mathrm{Hb}$ concentration was usually not determined.

This report was prompted by observation of the sinusoidal FHR pattern in several cases of fetal anemia and by the diverse opinions regarding the pathophysiology of the pattern.

\section{Material and methods}

The anemic fetuses were searched from the records of those fetuses which received transfusions or exchange transfusions in the years 1978 and 1979 at
Helsinki University Central Hospital. The cut-off level for $\mathrm{Hb}$ concentration in peripheral blood of the neonate was chosen $170 \mathrm{~g} /$ liter according to a normal material in the same hospital [9]. The cutoff level for umbilical $\mathrm{Hb}$ of the preterm babies and for $\mathrm{Hb}$ of intrapartum capillary blood of the samples was chosen from the report of BuRMAN and MORRIS [2].

Two-hundred and thirty-five among 11976 infants born during this two-year period $(2 \%)$ received transfusions or exchange transfusions. Eighty-three of them had thus defined anemia (0.7\%). This population was divided into two groups: 13 fetuses with $\mathrm{Hb}$ less than $80 \mathrm{~g} /$ liter (severe anemia) and 70 fetuses with $\mathrm{Hb}$ values between 80 and $169 \mathrm{~g} /$ liter (moderate anemia). The antepartum diagnoses, complications during labor and delivery, the mean durations of pregnancies, the mean weights of the newborn, the modes of delivery, and the fetal outcomes in these groups are shown in $\mathrm{Tab}$. I. $\mathrm{Hb}$ values were estimated as cyanmethemoglobin spectrophotometrically. Fetal anemia was detected in 19 fetuses by fetal blood analysis (FBA) performed according to SALING [19]. Neonatal anemia was detected from umbilical artery in 20 infants and from peripheral blood during the first day of life in 44 infants. All of these were presumed to have fetal anemia, since no neonatal bleeding was observed in them.

All fetuses were electronically monitored ante- or intrapartum. All CTGs except two (case one with abdominal and case six with direct electro-cardiography) were recorded by ultrasound. The cardio- 
Tab. I. The gestational ages at birth, birthweights, modes of delivery, complications and clinical diagnoses in 13 cases of severe and 70 cases of moderate fetal anemia.

\begin{tabular}{|c|c|c|}
\hline & $\begin{array}{l}\text { Severe } \\
\text { anemia }\end{array}$ & $\begin{array}{l}\text { Moderate } \\
\text { anemia }\end{array}$ \\
\hline \multicolumn{3}{|l|}{ Hemoglobin concentration } \\
\hline $\begin{array}{l}\mathrm{g} / \text { liter (mean } \pm \mathrm{SD} \text { ) } \\
\mathrm{N}\end{array}$ & $\begin{array}{l}57 \pm 16 \\
30-77 \\
13\end{array}$ & $\begin{array}{l}141 \pm 19 \\
106-169 \\
70\end{array}$ \\
\hline $\begin{array}{l}\text { Gestational age } \\
\text { at birth weeks }(\text { mean } \pm S D)\end{array}$ & $35.4 \pm 4.2$ & $35.2 \pm 4.1$ \\
\hline $\begin{array}{c}\text { Birthweight } g \text { (mean } \pm \text { SD) } \\
\text { (range) }\end{array}$ & $\begin{array}{l}2313 \pm 685 \\
1150-3150\end{array}$ & $\begin{aligned} 2420 & \pm 968 \\
575 & -4250\end{aligned}$ \\
\hline Cesarean sections & 10 & 32 \\
\hline Perinatal deaths & 4 & 7 \\
\hline APGAR score $<7$ & 8 & 27 \\
\hline \multicolumn{3}{|l|}{ Causes of anemia } \\
\hline - Rh-immunization & 7 & 35 \\
\hline - ABO-immunization & - & 3 \\
\hline - KELL-immunization & 1 & - \\
\hline $\begin{array}{l}\text { - Fetomaternal } \\
\text { transfusions }\end{array}$ & 3 & 1 \\
\hline - Fetofetal transfusions & - & 2 \\
\hline - Abruptio placentae & 2 & 5 \\
\hline - Unknown & - & 24 \\
\hline
\end{tabular}

tocograms were evaluated visually. Late decelerations (LD) were recorded when two or more late decelerations were observed. Silent pattern of FHR (SP) was recorded when baseline FHR variability was less than five beats per minute for five minutes or more. Sinusoidal FHR pattern was defined as smoothed, rounded oscillation of FHR two to three cycles per minute with an amplitude up to 40 beats per minute and lasting for at least one minute.

The control material consisted of 65 normal pregnancies, of which more than 500 samples of FHR were recorded by abdominal electrocardiography [11]. The incidence of abnormal FHR patterns in severe anemia was compared with that in moderate anemia to find out the possible' specific marker of anemia. The statistical significance was calculated by the $\chi^{2}$ test with YATES' correction.

\section{Results}

Thirty eight of the anemic fetuses showed late decelerations, 29 silent and nine sinusoidal FHR patterns. No abnormal FHR patterns were seen in the control material.

The clinical data and FHR patterns related to severe fetal anemia are shown in Tab. II and those related to moderate fetal anemia and sinusoidal FHR pattern in Tab. III. Late decelerations and sinusoidal patterns were significantly more often associated with severe than with moderate anemia (Tab. IV). Silent pattern of FHR was also more often associated with severe than with moderate anemia, but the difference was not significant in this material.

The fetal outcome after the sinusoidal FHR pattern was poorer than after FHR patterns without sinusoidal periods, but the differences were not significant in this material (Tab. V).

The nine sinusoidal FHR patterns found in this material are reproduced in Fig. 1a and Fig. 2. In all but case one, the sinusoidal FHR pattern was intermittent. Five other FHR patterns with suspected sinusoidal patterns were found in the group of severe fetal anemia (Fig. 1b).

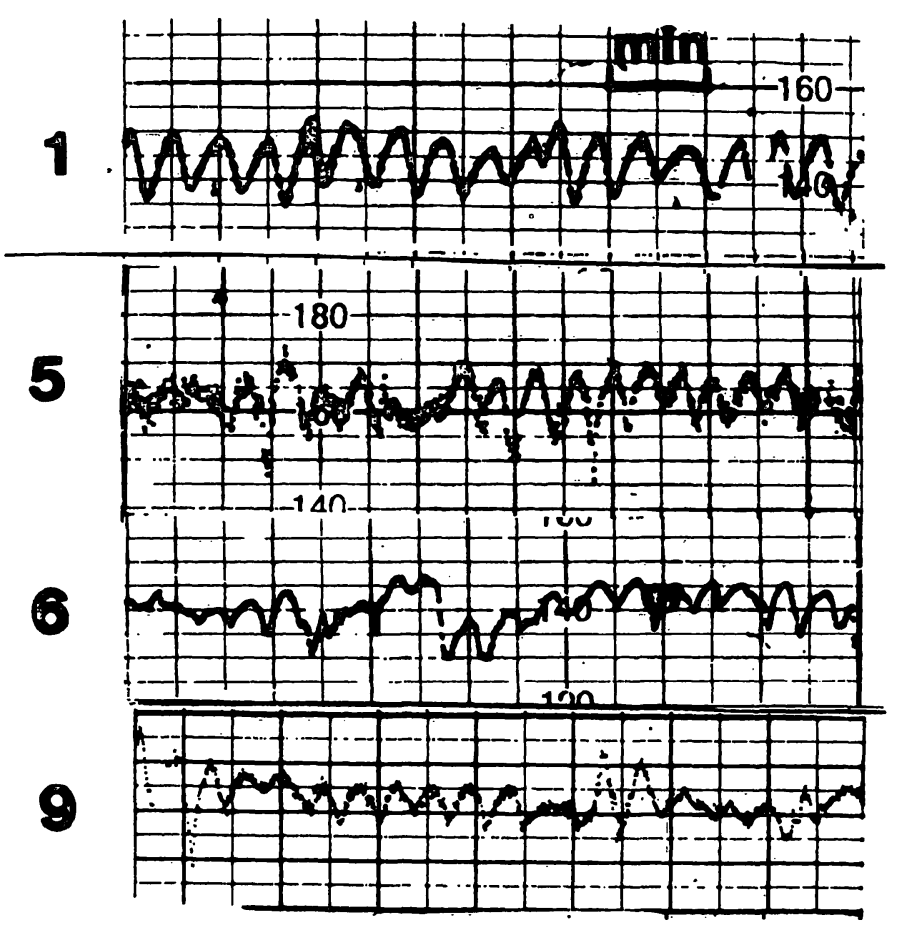

Fig. 1a. The sinusoidal periods of cardiograms found in fetuses with severe anemia. 
Tab. II. The clinical data and fetal heart rate patterns associated with severe fetal anemia.

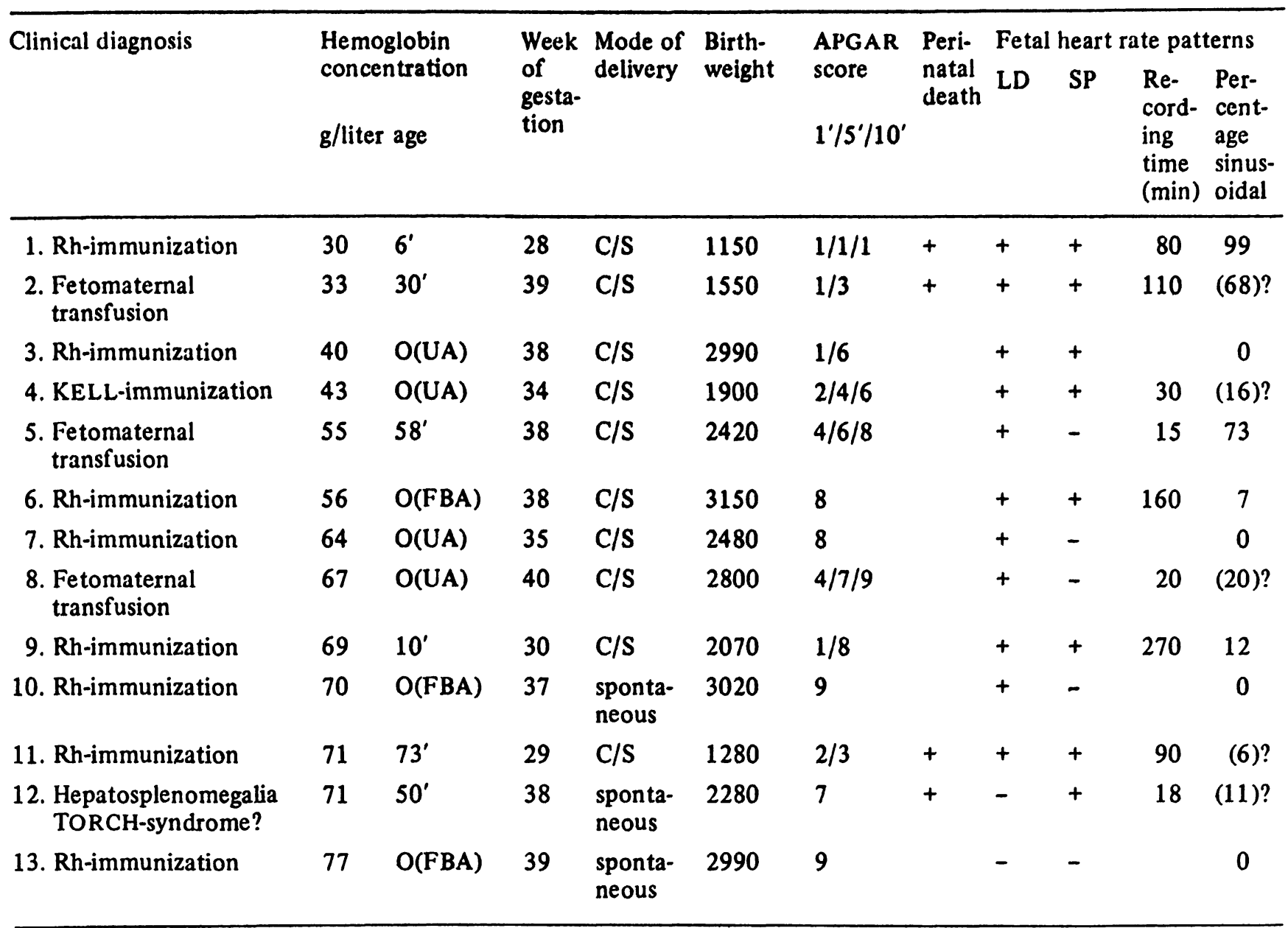

(UA $=$ umbilical artery, $\quad F B A=$ fetal blood analysis, $\quad C / S=$ caesarean section, $\quad L D=$ late decelerations, $S P=$ silent pattern (less than five beats per minute) of fetal heart rate)

Tab. III. The clinical data and fetal heart rate patterns associated with moderate fetal anemia and sinusoidal fetal heart rate pattern.

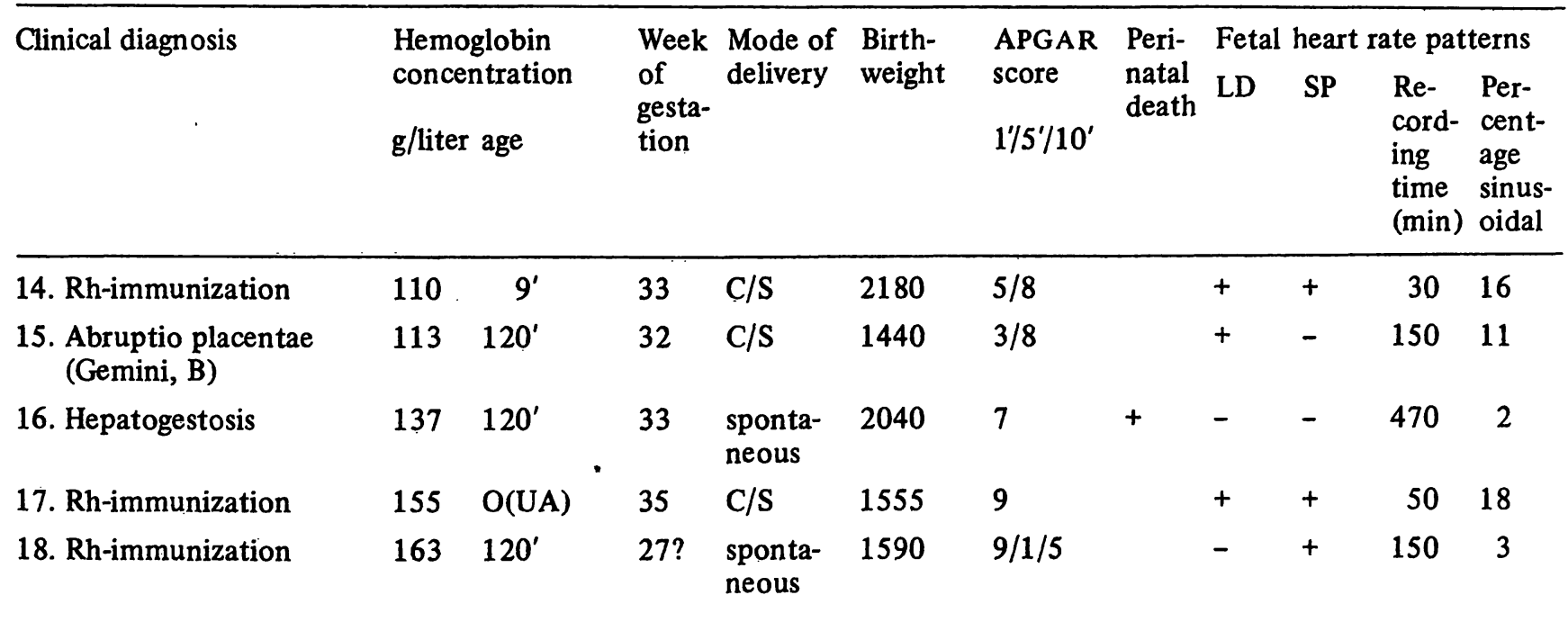

(UA = umbilical artery, $\mathrm{C} / \mathrm{S}=$ caesarean section, $\mathrm{LD}=$ late decelerations, $\mathrm{SP}=$ silent pattern (less than five beats per minute) of fetal heart rate)

J. Perinat. Med. 10 (1982) 


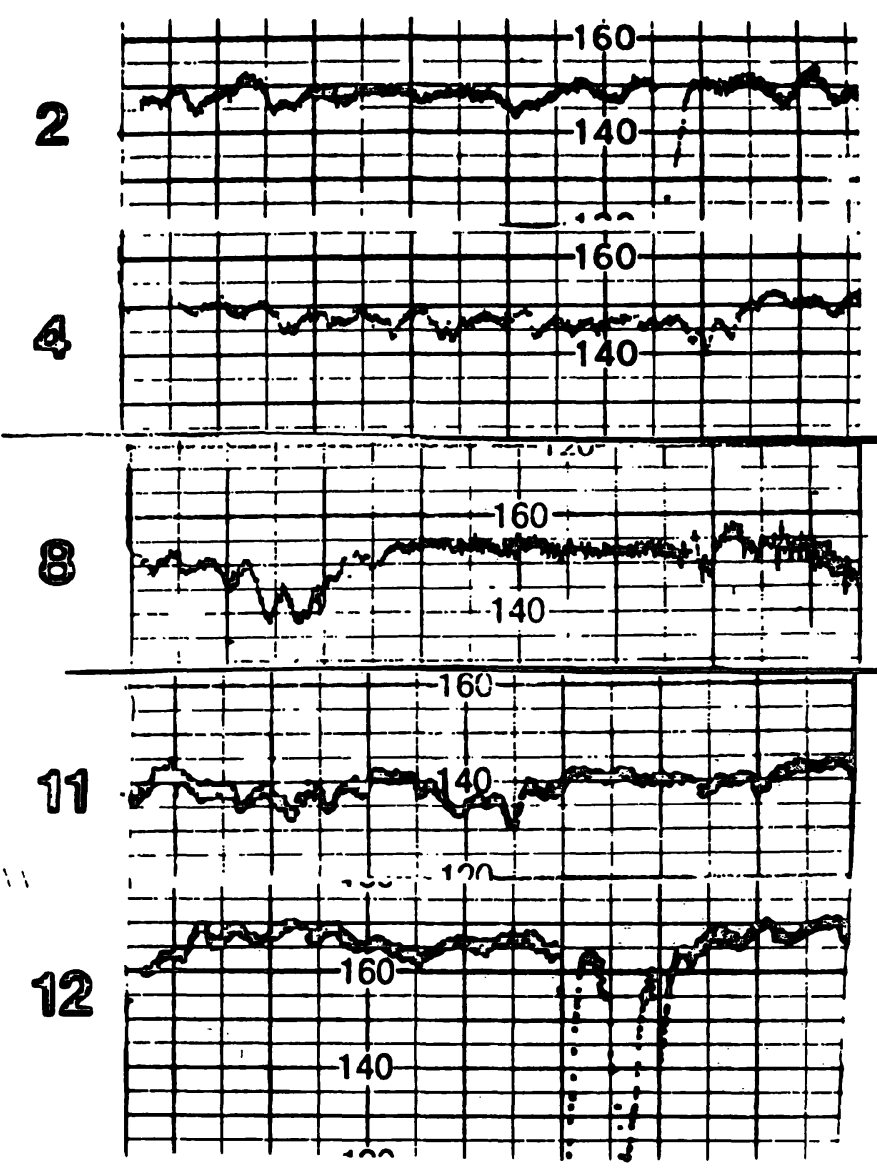

Fig. 1b. The suspected sinusoidal periods of cardiograms found in fetuses with severe anemia.

Tab. IV. Fetal heart rate patterns associated with severe and moderate fetal anemia.

\begin{tabular}{llrll}
\hline & & $\begin{array}{c}\text { Severe } \\
\text { anemia }\end{array}$ & $\begin{array}{l}\text { Moderate p } \\
\text { anemia }\end{array}$ & \\
\hline Late & yes & 11 & 27 & \\
decelerations & no & 2 & 43 & $<0.01$ \\
Silent pattern & yes & 8 & 21 & \\
& no & 5 & 49 & NS \\
Sinusoidal & yes & 4 & 5 & \\
& no & 9 & 65 & $<0.05$ \\
\hline
\end{tabular}

Tab. V. The sinusoidal fetal heart rate pattern as an indicator of fetal outcome.

\begin{tabular}{lllrl}
\hline & & \multicolumn{3}{l}{ Sinusoidal } \\
& & \multicolumn{2}{l}{ fetal heart rate } & \\
& & Yes & No & p \\
\hline APGAR score $<7$ & yes & 6 & 29 & NS \\
& no & 3 & 45 & \\
Perinatal death & yes & 2 & 9 & NS \\
& no & 7 & 65 & \\
\hline
\end{tabular}

A negative, but not significant linear correlation $(r=-0.68)$ was found between fetal $\mathrm{Hb}$ concentration and the percentage of the sinusoidal pattern.

\section{Discussion}

This study supports the earlier reports which indicate that sinusoidal FHR pattern is suggestive of fetal anemia. In this material late decelerations were even more often associated with anemia than sinusoidal pattern, but they are known to be less specific markers of anemia. Most often they are observed in association with uteroplacental insufficiency. Late decelerations probably indicate impairment of the oxygen transport during contractions, due to reduced volume of hemoglobin. According to the present study, the cause of fetal anemia and sinusoidal FHR pattern may be blood

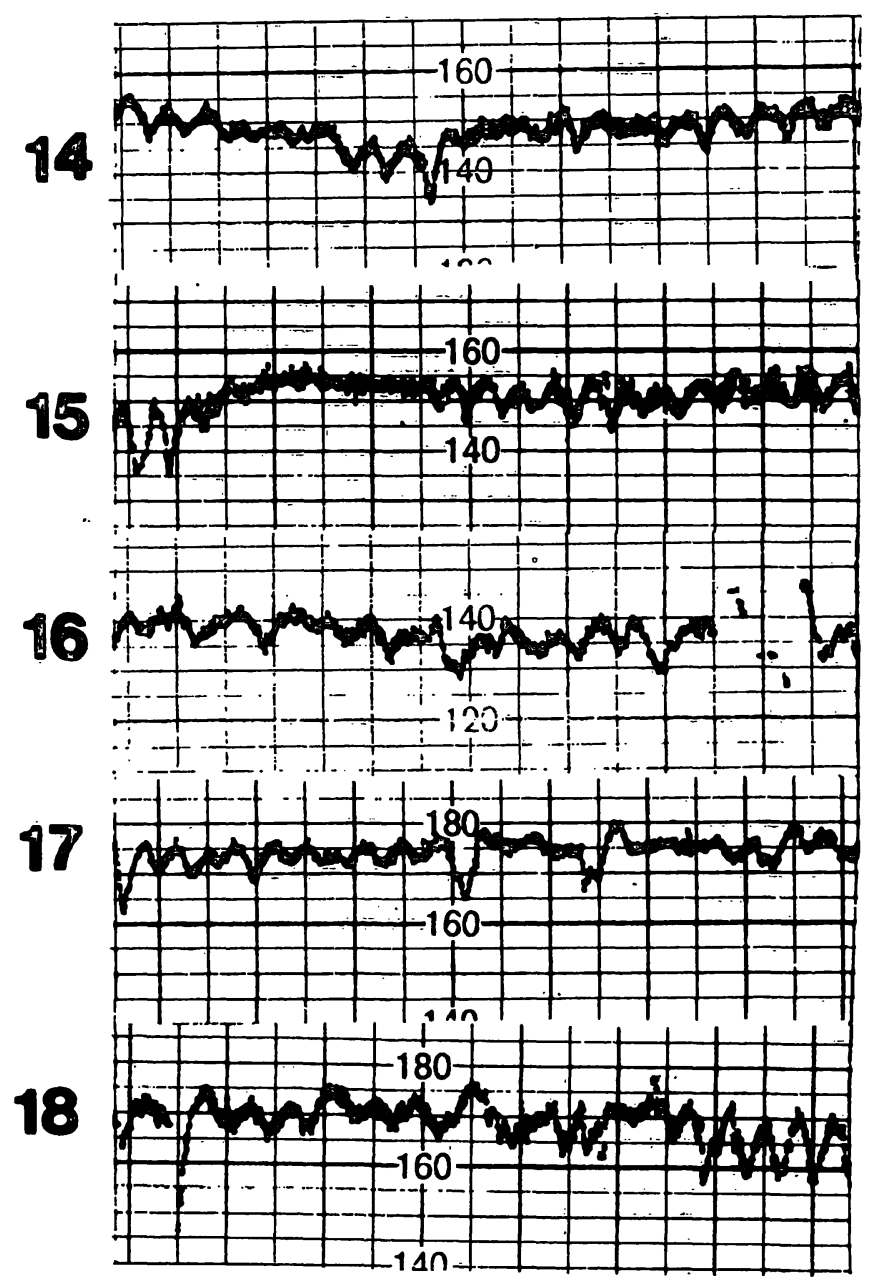

Fig. 2. The sinusoidal cardiograms recorded from fetuses with moderate anemia. 
group incompatibility with subsequent hemolytic disease of the fetus or fetal haemorrhage in fetomaternal or fetofetal transfusion and abruptio placentae. Thus this material does not support some previous suggestions that sinusoidal FHR pattern would be peculiar to $\mathrm{Rh}$-immunization $[14,18,7,22]$ except in the sense that Rh-disease causes more difficult hemolysis than other immunizations.

The sinusoidal FHR patterns described in this report were found by surveying the records of anemic neonates. Thus it does not give any answer to the question whether or not the other suggested causes of sinusoidal pattern, such as placental insufficiency [13] or postmaturity [4] as such, exist. Recently we have found one sinusoidal FHR pattern in a postmature fetus, but a coexisting anemia was also detected. Our recent material of FHR variability with more than 500 samples of FHR recorded by abdominal fetal electrocardiography during 65 normal pregnancies does not contain a single sinusoidal period, nor does the group of suspected intrauterine growth retardation contain it [11].

It has been suggested that a sinusoidal FHR pattern is a sign of impending fetal death $[16,7,10]$. In this material the fetal outcome after the sinusoidal FHR pattern was poorer than without this pattern, but the difference was not significant. This study supports the previous investigations $[16,7]$ showing that in some cases even a severely anemic fetus with a sinusoidal FHR pattern (cases 3 and 4) can be saved with cesarean section, if the pattern is recognised.

A previous study suggested that a fetal blood analysis for determination of blood $\mathrm{pH}$ should be performed when a sinusoidal FHR pattern is observed during labor [20]. We agree with another report [1] that a more comprehensive FBA with determination of $\mathrm{Hb}$ concentration and blood group should be performed. It should also be considered during the antepartum period, if amniotic fluid is found to be mature. A KLEINHAUERBETKE test on maternal blood for fetal $\mathrm{Hb}$ might be helpful in diagnosing the fetomaternal transfusion. In this material, the test was found to be positive in one case (case 8 ) and negative in two (cases 2 and 5).
The sinusoidal FHR pattern was intermittent in this material in all but one case (case 1), in which $\mathrm{Hb}$ concentration was lowest. Thus this study gives some support to a previous suggestion [22] that a continuous sinusoidal pattern has an ominous and possibly agonal significance. It is, however, possible to save even these fetuses with cesarean section [16] or intrauterine transfusion and cesarean section [7]. It should also be noted that even with a fairly low fetal $\mathrm{Hb}$ (cases 2 and 4 ) the sinusoidal pattern is only intermittently observable. The changing amplitude of the sinusoidal pattern (as in Fig. 2) even to a silent patterns (as in case 8) makes the pattern intermittent and difficult to recognize [14]. The low amplitude of the sinusoidal pattern (as in cases 2, 4 and 11) makes them even more difficult to recognize, especially if the beat-to-beat recording has failed.

The intermittent nature of the sinusoidal FHR pattern also gives a possible explanation for the fact that it has been observed in some cases only before [7] or only after [17] the intrauterine transfusion. The intrauterine transfusion was performed on six fetuses in this series. In one case (case 17) the sinusoidal pattern was observed only after two transfusions. It was seen before and after the transfusion in two cases (cases 4 and 9) and it was not seen at all in association with three transfusions. The transfusion procedure itself could hardly be the cause of the sinusoidal FHR pattern.

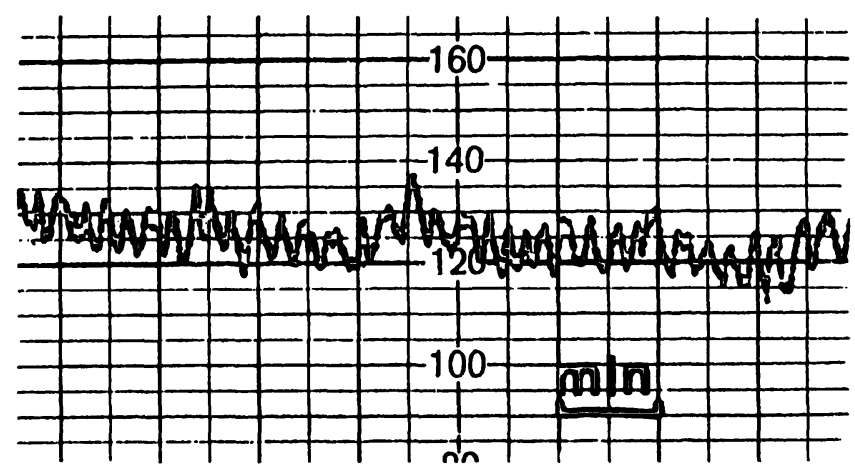

Fig. 3. The sinusoidal-simulating pattern of fetal heart rate recorded one hour after intramuscular pethidine was given to the mother. The sinusoidal patterns associated with fetal anemia have morc rounded and smoothed pattern and a lower frequency. 
A recent report suggested that alphaprodine (a narcotic analgesic) administered to the mother could be the cause of a sinusoidal FHR pattern [6]. We observed a similar change of FHR after administration of intramuscular pethidine to the mother (Fig. 3). This pattern, however, lacks the smoothing and rounding which is so peculiar to

\section{Summary}

A retrospective survey was performed of the clinical records and cardiotocograms (CTG) of fetuses born in 1978 and 1979 at Helsinki University Central Hospital with hemoglobin concentration less than $170 \mathrm{~g} /$ liter in peripheral blood or umbilical artery. Eighty-three fetuses $(0.7 \%)$ had thus defined anemia. Thirty-eight of them had late decelerations, 29 silent and nine sinusoidal fetal heart rate (FHR) patterns. Late decelerations and sinus-

Keywords: Anemia, fetus, heart rate.

\section{Zusammenfassung}

Fetale Anämie und Herzfrequenzmuster

Von den zwischen 1978 und 1979 im ,Helsinki University Central Hospital" geborenen Kindern mit einem Hämoglobinwert von $<170 \mathrm{~g} / 1 \mathrm{im}$ peripheren Blut oder in der Nabelarterie, wurde eine retrospektive Studie der Krankengeschichte und der Kardiotokogramme (CTG) durchgeführt. 83 der Kinder $(0,7 \%)$ hatten eine solche Anämie.

38 von ihnen hatten späte Dezelerationen, 29 eine stumme und 9 eine sinusähnliche fetale Herzfrequenz

Schlüsselwörter: Anämie, Herzfrequenz, Neugeborenes. the sinusoidal pattern due to fetal anemia. It also has a higher frequency than, the sinusoidal pattern. In conclusion, typical FHR patterns for fetal anemia are late decelerations observed with periods of intermittent sinusoidal pattern, which probably becomes continuous with worsening anemia.

oidal patterns were significantly more often associated with severe (hemoglobin concentration less than $80 \mathrm{~g} /$ liter) than with moderate anemia. The fetal outcome in terms of perinatal death and low APGAR scores after sinusoidal pattern was poorer than without this pattern, but the difference was not statistically significant. It is concluded that intermittent sinusoidal FHR pattern with late decelerations is suggestive of fetal anemia.

(FHF). Späte Dezelerationen und sinusähnliche Muster gingen signifikant häufiger mit einer schweren Anämie (Hämoglobinwert $80 \mathrm{~g} / \mathrm{l}$ ) einher, denn mit einer milden Anämie. Zwar waren die Folgen für die Neugeborenen (perinatale Sterblichkeit und APGAR scores) mit sinusähnlichen Mustern schlechter als ohne diese Muster, doch war der Unterschied statistisch nicht signifikant. Zusammenfassend kann gesagt werden, daß ein intermittentes sinusähnliches FHF Muster mit späten Dezelerationen eine fetale Anämie vermuten läßt.

\section{Résumé}

Anémie fétale et tracés de fréquences cardiaques.

On a fait une étude rétrospective des histoires cliniques et cardiogrammes (CTG) d'enfants nés en 1978 et 1979, à „Helsinki University Central Hospital“, avec un taux d'hémoglobine inférieur à $170 \mathrm{~g} / 1$ dans le sang périphérique ou dans l'artère ombilicale: 83 enfants $(0,7 \%)$ avaient cette anémie précitée. 38 de ceux-ci avaient une décélération retardée, 29 un tracé de fréquence cardiaque fétale (FCF) silencieux et 9 un tracé de FCF sinusoïdale.

Mots-clés: Anémie, fétus, fréquence cardiaque.
Les décelerations retardées et les tracés sinuso ̈̈aux étaient plus fréquemment associés à une anémie sévère (concentration d'hémoglobine $<80 \mathrm{~g} / \mathrm{l}$ ) qu'à une anémie modérée. L'état fétal exprimé en termes de mort perinatal et de bas scores APGAR après le tracé sinuso ïdal était plus mauvais que sans ce tracé, mais cette différence n'était pas statistiquement significative.

En conclusion, on peut dire que le tracé de la FCF sinusoïdal intermittent avec décelerations retardées, suggère une anémie fétalè.

Acknowledgement: This work was supported by YRJÖ JAHNSSON Foundation.

\section{Bibliography}

[1] BASKETT, T. R., K. S. KOH: Sinusoidal fetal heart pattern. A sign of fetal hypoxia. Obstet. and Gynec. 44 (1974) 379
[2] BURMAN, D., A. MORRIS: Cord haemoglobin in low birthweight infants. Arch. Dis. Childh. 49 (1974) 382 
[3] CETRULO, C. L., B. S. SCHIFRIN: Fetal heart rate patterns preceding death in utero. Obstet. and Gynec. 48 (1976) 521

[4] CIBILS, L. A.: Clinical significance of fetal heart rate patterns during labor. IV Agonal patterns. Amer. J. Obstet. Gynec. 129 (1977) 833

[5] GAL, D., L. M. JACOBSON, H. SER, S. A. PARK, L. M. TANCER: Sinusoidal pattern: An alarming sign of fetal distress. Amer. J. Obstet. Gynec. 132 (1978) 903

[6] GRAY, J. H., D. W. CUDMORE, E. R. LUTHER, T. R. MARTIN, A. J. GARDNER: Sinusoidal fetal heart rate pattern associated with an alphaprodine administration. Obstet. and Gynec. 52 (1978) 678

[7] HATJIS, C. G., M. T. MENNUTI, L. M. SACKS, R. H. SCHWARZ: Resolution of a sinusoidal fetal heart rate pattern following intrauterine transfusion. Amer. J. Obstet. Gynec. 132 (1978) 109

[8] HENRION, R., L. HEARD: Un signal de détresse: La diminution des mouvements actifs du foetus. Une observation à l'anémie foetal grave. J. Gyn. Obst. Biol. Repr. 8 (1979) 539

[9] HOVI, L.: Hyperbilirubinemia of the newborn. Thesis, Helsinki University, Helsinki 1981

[10] JOHNSON, T., A. A. COMPTON, J. ROTMENSCH, B. A. WORK, J. W. C. JOHNSON: Significance of the sinusoidal fetal heart rate pattern. Amer. J. Obstet. Gynec. 139 (1981) 446

[11] KARINIEMI, V., P. ÄMMÄLÄ: Short term variability of fetal heart rate during pregnancies with normal and insufficient placental function. Amer. J. Obstet. Gynec. 139 (1981) 33

[12] KATZ, M., S. J. WILSON, B. K. YOUNG: Sinusoidal fetal heart rate. II. Continuous tissue $\mathrm{pH}$ studies. Amer. J. Obstet. Gynec. 136 (1980) 594

[13] KUBLI, F., H. RÜTTGERS, U. HALLER, C. BOGDAN, M. RAMZIN: Die antepartale fetale Herzfrequenz. II. Verhalten von Grundfrequenz, Fluktuation and Dezelerationen bei antepartalem Fruchttod. Z. Geburtsh. Perinat. 176 (1972) 309
[14] Manseau, P., J. Vaquier, J. ahavinié, C. SUREAU: Le rythme cardiaque foetal ,sinusoidal“". Aspect évocateur de souffrance foetale au cours de la grossesse. J. Gyn. Obst. Biol. Repr. 1 (1972) 343

[15] MERKUR, H.: Normal and abnormal antenatal ultrasonic cardiographic patterns. Brit. J. Obstet. Gynec. 86 (1979) 533

[16] MODANLOU, H. D., R. K. FREEMAN, O. ORTIZ, P. HINKES, P. PILLSBURY: Sinusoidal fetal heart rate pattern and severe fetal anemia. Obstet. and Gynec. 49 (1976) 537

[17] MUELLER-HEUBACH, E., S. N. CARITIS, D. I. EDELSTONE: Sinusoidal fetal heart rate pattern following intrauterine fetal transfusion. Obstet. and Gynec. 52 (1978) 435

[18] ROCHARD, F., B. S. SCHIFRIN, E. GOUPIL, H. LEGRAND, J. BLOTTIERE, C. SUREAU: Nonstressed fetal heart rate monitoring in the antepartum period. Amer. J. Obstet. Gynec. 126 (1976) 699

[19] SALING, E.: Neues Vorgehen zur Untersuchung des Kindes unter der Geburt. Arch. Gynäk. 197 (1962) 108

[20] SIBAI, B. M., J. LIPSHITZ, J. M. SCHNEIDER, G. D. ANDERSON, J. C. MORRISON, P. V. DILTS: Sinusoidal fetal heart rate pattern. Obstet. and Gynec. 55 (1980) 637

[21] THIESSEN, P., K. ROBINSON, A. T. SHENNAN: Intrapartum cardiac minitor abnormality associated with severe fetal anemia and hypoxia. Amer. J. Obstet. Gynec. 130 (1978) 731

[22] VERMA, U., N. TEJANI, R. R. WEISS, S. CHATTERJEE, V. HALITSKY: Sinusoidal fetal heart rate patterns in severe $R h$ disease. Obstet. and Gynec. 55 (1980) 666

[23] YOUNG, B. K., M. KATZ, S. J. Wilson: Sinusoidal fetal heart rate. I. Clinical significance. Amer. J. Obstet. Gynec. 136 (1980) 587

Received December 10, 1981. Accepted February 1, 1982.

Veikko Kariniemi, M.D.

1st Department of Obstetrics and Gynecology, Helsinki University Central Hospital

Haartmanink. 2

SF-00290 Helsinki 29

Finland 